\title{
The Effect of Self-Efficacy And Work Motivation on The Organizational Commitment and its Implication on The Employee Performance of Local Government in Aceh Jaya District
}

\author{
Burhanis Sulthan DM' ${ }^{1}$, Rahman Lubis ${ }^{2}$, Sulaiman ${ }^{3}$ \\ Master Management of Postgraduate Program University of Syiah Kuala Banda Aceh ${ }^{1}$ \\ Faculty of Economics University of Syiah Kuala ${ }^{2,3}$ \\ \{burhanis.dm@gmail.com\}
}

\begin{abstract}
The paper analyzes the effect of self-efficacy and works motivation on the organizational commitment and its implication on the employee performance of local government in Aceh Jaya district. The samples are 287 civil servants that are selected by proportional sampling from a number of public institutions in the district. The data is collected by using a questionnaire and then it is analyzed by using statistical means of structural equation modeling AMOS to analyze functional relation among variables. The research finds that self-efficacy and work motivation have a positive and significant effect on the improvement of organizational commitment and employee performance. The existence of the organizational commitment is not only to improve the effect of self-efficacy and work motivation on employee performance but also it has been mediating variables among the variables.
\end{abstract}

Keywords: Employee performance, organizational commitment, self-efficacy, and work motivation.

\section{Introduction}

The performance of an employee, theoretically, is related to a number of factors such as organizational commitment, self-efficacy and work motivation [1]. Organizational commitment reflects a sense of employee attachment to the organization where the employee works. The relationship between employee performance and organizational commitment is caused by the employees with high commitment or sense of attachment who have the desire to make extra contributions to the organization and want to carry out work beyond the workload which is given to them [2]. Organizational commitment is also a determining factor for work behavior and employee performance [3]. Organizational commitment is often reflected in the sincerity of employees in their work and the desire to make the best contribution to support operational activities of the organization. The conditions can have positive impact on employee performance. This implies that the higher the commitment of an employee to the institution where he works, the higher the performance of the employee.

Basically, self-efficacy is the claim of an employee about his ability to plan and to carry out an activity which is needed to achieve the performance targets that are previously made [4]. The trust in the ability of oneself in completing a job, encouraging someone to work harder to realize 
the work plan that has been made. This implicitly indicates that self-efficacy can have a positive impact on the formation of employee performance. Empirical studies which are conducted by Judge \& Bono [5] have proven there is a positive relation between these two variables. Similar to the study of Erez \& Judge [6] also concludes that there is a positive impact of self-efficacy on individual performance.

Furthermore, work motivation is the willingness of a person to direct his will, expertise, and skills at work [7]. Work motivation is also one of the important determinants of employee productivity and performance [8]. Even the differences in work motivation in an employee can be seen from the success of the employee in carrying out their duties in accordance with the workload and responsibilities that are given[9]. The research findings of Muogbo [10] also provide empirical evidence about the existence of unidirectional relation between the two variables.

In order to provide public services in the area, the government of Aceh Jaya district has a number of agencies in which their operational activities are directly responsible to the regent as the regional head. All Regional Government Work Units / Satuan Kerja Pemerintah Daerah (SKPD) are expected to be able to support the achievement of the district vision.

The results of interviews with several employees at one of the agencies within the government of Aceh Jaya district provides the initial fact that their performance is relatively different. On one hand, there are employees who have good performance, this is characterized by the ability to complete work on time, always strive to maintain discipline in work, and have good responsibility for all jobs that are charged. On the other hand, there are also some employees with poor performance. Those who are included in this group not only have problems with the completion of the workload that has been given, but are also less responsible for the problems that arise in relation to the field of work that is assigned to them.

As it is stated earlier, employee performance is theoretically and empirically related to organizational commitment. In addition, employee performance is also related to self-efficacy and work motivation. So the question is whether employee performance of the government in Aceh Jaya district is related to organizational commitment, self-efficacy and work motivation.

\section{Literature Review}

\subsection{The Effect of Self-Efficacy on Organizational Commitment}

Self-efficacy can be seen as a person claim to the ability he has to work on activities that must be carried out in order to realize predetermined work target [11]. A person with relatively good self-efficacy will tend to be more confident with himself that he is able to carry out the assigned work. This belief can have an impact on the desire to complete the work as well as possible, and he has a strong sense of attachment to the organization where he works. The relation between self-efficacy and organizational commitment as it is stated by Agarwal \& Mishra [12] self-efficacy can have an impact on organizational commitment. Employees with good self-efficacy have the self-confidence that the work that is charged can be resolved properly. The emotional conditions have an impact on the seriousness in carrying out work and he desires that the work that is done can be beneficial for the organization where he works. Seriousness in work and the desire to provide the best for the organization are important indicators of organizational commitment.

Based on the description above, it is explicit and understandable that an employee attachment to the organization where he works is related to self-efficacy that is in him. The better the selfefficacy that is characterized by the confidence in completing the work that is charged, the better 
the commitment or sense of attachment to the organization. Conversely, a person with less good self-efficacy usually lacks confidence in his ability to work, is easily broken up and saturated with work. Finally, the desire to provide the best for the organization is also lower.

\subsection{The Effect of Work Motivation on Organizational Commitment}

Work motivation can be one of the determinants in an organization. Employees with relatively good work motivation usually have relatively greater urge to complete the work that is charged so that it has a positive impact on the organization. Work motivation does not only make an employee feel closer to his job but also can increase the sense of attachment to the organization where he works.

The influence of work motivation on organizational commitment empirically has been proven by the research of Krishna, Herd, \& Aydinoğlu [13] who conclude that work motivation has a significant impact on increasing organizational commitment. In line with the findings, the study results of Salleh, Zahari, Said, \& Ali [14] and Al-Madi, Assal, Shrafat, \& Zeglat [15]. Also, reveal that the increasing in work motivation can increase organizational commitment.

\subsection{The Effect of Self-Efficacy on Employee Performance}

Employee performance can be determined by several factors such as compensation and work motivation Akmal, Lubis., \& Yunus [16] work culture and work motivation Kurniawan, Lubis, \& Adam [17]; and work motivation and organizational culture [18]. Another factor that can influence employee performance is self-efficacy. Self-efficacy encourages the improvement of employee performance individually. The study results of Judge \& Bono[5] by using a metaanalysis concluded that there is a positive relationship between these two variables. The findings are in line with the research of Erez \& Judge [6] who also present the same conclusions in which self-efficacy has a positive impact on the formation of employee performance.

\subsection{The Effect of Work Motivation on Employee Performance}

The willingness of employees to do a job is usually driven by the willingness or desire that they want to get by doing the work. Employees hope that the work they do can meet their needs [19]. This is based on the logical reason that every employee is faced with a number of needs that they must fulfill. The efforts to fulfill the needs are one of the main reasons that they are willing and ready to carry out work [20]. The intensity of work motivation in an employee becomes a determinant of employee performance[9]. The unidirectional relation between employee performance and work motivation implicitly can be explained that work motivation can encourage the increase in effectiveness and work productivity and efficiency in carrying out work [20].

\subsection{The Effect of Organizational Commitment on Employee Performance}

Commitments reflect the sense of attachment from the employees to the organization in which they work. When employees have a high commitment, the tendency to seriously carry out each assigned job will also be high. So the opportunity to be able to complete all tasks will also increase. This forms the framework of thinking that commitment is in line with the work that can be achieved by employees. Conversely, when employees have the low commitment, the motivation and desire to work better will also be low. Even low commitment can have an 
impact on the employee desire for turnover (changing jobs, or leaving the organization where he works).

This is in line with the opinion of [21] who reveals that commitment or a sense of attachment to the organization reflects the desire to provide the best for the organization. Wentzel [22] finds that employee performance is positively and significantly related to organizational commitment.

\subsection{The Relation between Self-Efficacy and Work Motivation}

Self-efficacy is related to self-confidence in a person that he can perform tasks well. One who believes that he is capable of working usually will tend to succeed in carrying out every task which is given. Conversely when one feels unsure of his abilities and even feels anxious about the failure in work, then the opportunity to succeed will be smaller [23].

Trust in work ability correlates with motivation and job satisfaction. This is because selfconfidence can be a driving factor for work motivation. The relation between work motivation and self-efficacy has been proven in the research of Judge \& Bono [5] who conclude that high work motivation is in line with the self-efficacy of employees.

\subsection{The Effects of Self Efficacy on Employee Performance Through Organizational Commitment}

The effect of self-efficacy on employee performance can occur through a number of factors including organizational commitment. This is because self-efficacy basically can be interpreted as a justification in a person related to his ability to carry out a series of activities which are needed to achieve predetermined work target [11]. A person with relatively good self-efficacy will tend to be committed to carrying out the work which is assigned to him because he is motivated by a sense of trust in his ability to complete tasks. In other words, self-efficacy can have an impact on employee commitment to the organization in which the employee works [12].

The increase in employee commitment as a result of good self-efficacy in him will have an impact on the seriousness in carrying out every job that is charged so that the achievement of the task or performance increases. This is consistent with the opinion of [22] who explicitly emphasizes that employee performance is positively and significantly influenced by organizational commitment.

\subsection{The Effect of Work Motivation on Employee Performance of Organizational Commitment}

The influence of work motivation on employee performance can also occur through several channels, including organizational commitment. As it is explained earlier, work motivation can have an impact on the formation of organizational commitment[14], [15]. The increase in organizational commitment as the result of work motivation can ultimately influence the work performance of an employee. This is due to the fact that the employees who have the relatively high commitment or sense of attachment to the organization in which they work for will usually make every effort to support the efforts to achieve the organization goals [22].

\section{Research Methods}

This study is conducted at the Government of Aceh Jaya District. The object of the study relates to the relation between employee performance within the district government and 
organizational commitment, self-efficacy and work motivation. In this case, organizational commitment is positioned as an intermediate variable between employee performance and selfefficacy with work motivation.

The study sample consists of 287 civil servants working for a number of public agencies in the area. The data is collected through questionnaires which contain closed questions. Then it is analyzed by SEM-AMOS multivariate statistics.

\section{Result and Discussion}

Self-efficacy and work motivation influence organizational commitment and employee performance. In addition, organizational commitment also directly influences employee performance. It means organizational commitment can be interpreted as an intermediary between self-efficacy and work motivation on one hand, and employee performance on the other. In other words, self-efficacy and work motivation cannot only directly influence OCB, but can also be through organizational commitment as an intervening variable.

The estimated coefficient value of each exogenous construct for organizational commitment is 0.392 for self-efficacy and 0.326 for work motivation. This numbers can be interpreted that the direct effect of self-efficacy on organizational commitment is 15.37 percent, and the direct effect of work motivation on organizational commitment is 10.63 percent.

Furthermore, the estimated coefficient value of the two exogenous constructs on employee performance is 0.374 for self-efficacy and 0.299 for work motivation. Referring to the estimated coefficient value of the two variables, it can be interpreted that the direct effect of self-efficacy on employee performance is 13.99 percent, and the direct effect of work motivation on employee performance is 8.94 percent.

The estimated coefficient of organizational commitment to employee performance is 0.391 . This number can be interpreted that the direct effect of organizational commitment on employee performance is 15.29 percent. Furthermore, the estimated coefficient of self-efficacy on organizational commitment is 0.392 and the path coefficient of organizational commitment to employee performance is 0.391 . Thus the indirect effect of self-efficacy on employee performance through organizational commitment is 15.33 percent which is greater than the direct effect of self-efficacy on employee performance at 13.99 percent. Thus it can be interpreted that organizational commitment can strengthen the effect of self-efficacy on employee performance.

The estimated coefficient of working motivation on organizational commitment is 0.326 and the coefficient value of organizational commitment on employee performance is 0.391 so that the indirect effect of work motivation on employee performance through organizational commitment is 12.75 percent. This figure is also greater than the direct effect of work motivation on employee performance at 8.94 percent. So that it can be interpreted that organizational commitment does not strengthen the effect of work motivation on employee performance.

\section{$5 \quad$ Research Implications}

Theoretical implications are related to the comparison of research findings with theoretical foundations and empirical findings that are conducted by previous researchers. The research findings that provide empirical evidence of the effect of self-efficacy on organizational commitment are consistent with the findings of Agarwal \& Mishra [12] who conclude that selfefficacy can have an impact on organizational commitment. 
This study also provides strong evidence that work motivation can increase organizational commitment. This finding is consistent with the study results which are conducted by Krishna [13] who reveal empirical evidence that work motivation has positive and significant impact on organizational commitment. The study results of Salleh [14] and Al-Madi [15] also conclude that the increase in work motivation can increase organizational commitment.

As it is explained earlier, this study finds that self-efficacy has a positive and significant effect on employee performance. This finding supports the study results of Judge \& Bono [5] who prove there is a positive relation between the two variables. The study of Erez \& Judge [6] also proves that employee performance is positively related to self-efficacy.

Managerial implications relate to the implications of research findings for related parties, especially the Head of SKPD within the Government of Aceh Jaya District. The research findings indicate there is a positive and significant influence on self-efficacy and work motivation on commitment. It implies that the efforts to increase commitment or a sense of employee attachment to the agency which they lead can be done through policy interventions. They are related to increasing self-efficacy and work motivation within employees.

Organizational commitment can mediate the effect of self-efficacy and work motivation on employee performance. This implies that the efforts to increase commitment or a sense of attachment of employees to the institutions in which they work are very important for improving the performance of employees in carrying out their assigned tasks.

\section{Conclusion and Recommendation}

\subsection{Conclusion}

Self-efficacy has a positive and significant effect on organizational commitment of the employee to the Regional Government of Aceh Jaya District. Employees with relatively good self-efficacy have a commitment or a sense of attachment that is relatively strong towards the agency in which they work. Conversely, employees with less good self-efficacy, have low organizational commitment.

Work motivation has a positive and significant effect on organizational commitment of the employee to the Regional Government of Aceh Jaya District. The higher the work motivation in an employee, the higher the commitment or sense of attachment of the employee to the agency in which he is assigned. Conversely, employees with relatively low work motivation tend to have commitments that are also relatively low.

Self-efficacy has a positive and significant effect on employee performance in the Regional Government of Aceh Jaya District. The increasing of self-efficacy in an employee significantly influences the respective employee performance. Conversely, a decrease in self-efficacy can cause a decrease in employee performance.

Work motivation has a positive and significant effect on the employee performance in the Regional Government of Aceh Jaya District. The increase of work motivation can significantly improve employee performance in the government. Conversely, a decrease in work motivation has a negative impact on employee performance.

Self-efficacy influences employee performance in the Government of Aceh Jaya District through organizational commitment as an intervening variable. The role of organizational commitment as an intermediary variable between the two variables is partial mediation.

Work motivation influences employee performance in the Government of Aceh Jaya District through organizational commitment as an intervening variable. The mediating effect which is played by organizational commitment in mediating the two variables is partial mediation. 


\subsection{Recommendation}

The head of SKPD in the Government of Aceh Jaya District needs to increase employee commitment to the agencies which he leads. In operation, the increase in commitment or feeling of employee attachment to the agencies which they work in is not only done by developing values and norms that must not be only obeyed by all employees but must also pay attention to the values and norms that are adopted by the employees in general. So that the employees feel the equality of values and norms that they adhere to the system of values and norms that exist in their work environment.

The head of SKPD in the Government of Aceh Jaya District needs to improve the self-efficacy of his subordinate employees. Increase the employee confidence in carrying out tasks and provide support for each of them in carrying out the responsibilities that are given to. When employees face problems in the workplace, employers must be able to generate employee confidence in overcoming the problems that they face.

The head of SKPD in the Government of Aceh Jaya District needs to increase the work motivation of his employees. The increase in work motivation must be done by encouraging the emergence of desires in employees to improve the quality of their work and increase their sense of responsibility towards the completion of the tasks that are assigned. In addition, provide understanding for each employee about the importance of achieving work targets in accordance with the work plan that they have made.

\section{REFERENCES}

[1] K. Amri, "Pengaruh perilaku kepemimpinan dan motivasi dalam meningkatkan produktivitas kerja karyawan PT bank sinarmas Tbk cabang Banda Aceh,” J. Ekon. Manaj. dan Bisnis, vol. 3, no. 1, pp. 522-536, 2015.

[2] P. M. Podsakoff, S. B. MacKenzie, J. B. Paine, and D. G. Bachrach, "Organizational citizenship behaviors: A critical review of the theoretical and empirical literature and suggestions for future research," J. Manage., vol. 26, no. 3, pp. 513-563, 2000.

[3] D. W. Organ, P. M. Podsakoff, and S. B. MacKenzie, Organizational citizenship behavior: Its nature, antecedents, and consequences. Thousand Oaks, CA: Sage, 2006.

[4] A. Bandura, "Social cognitive theory of self-regulation," Organ. Behav. Hum. Decis. Process., vol. 50, p. 248-287., 1991.

[5] T. A. Judge and J. E. Bono, "Relationship of core self evaluations traits-self esteem, generalized self efficacy, locus of control and emotional stability-eith job satisfaction and performance: A meta analysis," J. Appl. Psychol., vol. 86, no. 1, pp. 80-92, 2001.

[6] A. Erez and T. A. Judge, "Relationship of core self-evaluations to goal setting, motivation, and performance," J. Appl. Psychol., vol. 86, no. 6, pp. 1270-1279, 2001.

[7] J. Segal, Melejitkan kepekaan emosional/boost emotional sensitivity,. Bandung, 2010.

[8] Ratnawati and K. Amri, "Pengaruh keadilan organisasional, kepercayaan pada atasan terhadap perilaku kewargaan organisasi (organizational citizenship behavior)," J. Ekon. Manaj. dan Bisnis, vol. 1, no. 1, pp. 56-73, 2013.

[9] H. H. B. Uno, Teori motivasi \& pengukurannya: analisis di bidang pendidikan. Jakarta: Bumi Aksara, 2010.

[10] U. S. Muogbo, "The impact of employee motivation on organisational performance (a study of some selected firms in anambra state nigeria)," Int. J. Eng. Sci., vol. 2, no. 3, pp. 134-151, 2013.

[11] A. Bandura, "Much ado over a faulty conception of perceived self-efficacy grounded in 
faulty experimentation,” J. Soc. Clin. Psychol., vol. 26, no. 6, pp. 641-658, 2007.

[12] S. Agarwal and P. C. Mishra, "Self-efficacy as predictor of organizational commitment among revenue personnel," Int. J. Indian Psychol., vol. 3, no. 4, pp. 43-52, 2016.

[13] A. Krishna, K. B. Herd, and N. Z. Aydinoğlu, "Wetting the bed at twenty-one: Embarrassment as a private emotion," J. Consum. Psychol., vol. 25, no. 3, pp. 473-486, 2015.

[14] S. M. Salleh, A. S. M. Zahari, N. S. M. Said, and S. rapidah O. Ali, "The influence of work motivation on organizational commitment in the workplace," J. Appl. Environ. Biol. Sci., vol. 6, no. 5S, pp. 139-143, 2016.

[15] F. N. Al-Madi, H. Assal, F. Shrafat, and D. Zeglat, "The impact of employee motivation on organizational commitment," Int. J. Bus. Manag., vol. 9, no. 15, pp. 134-145, 2017.

[16] Z. Akmal, A. R. Lubis., and M. Yunus, "Pengaruh kompensasi terhadap motivasi dan disiplin serta dampaknya kepada kinerja pegawai sekretariat daerah Aceh Unsyiah.," $J$. Manaj., vol. 2, no. 1, pp. 116-131, 2012.

[17] D. Kurniawan, A. R. Lubis, and M. Adam, "Pengaruh budaya kerja dan motivasi kerja terhadap kinerja karyawan international federation red Ccross (IFRC) Banda Aceh," $J$. Ilmu Manaj., vol. 1, no. 1, pp. 132-146, 2012.

[18] M. A. Yazid, S. Musnadi, and S. Chan, "Pengaruh gaya kepemimpinan, budaya organisasi dan motivasi kerja terhadap prestasi pegawai administrasi serta dampaknya pada kinerja politeknik negeri lhokseumawe, Aceh," J. Manaj., vol. 2, no. 1, pp. 78-87, 2013.

[19] M. As’ad, Psikologi industri/industrial psychology,. Yogyakarta: Liberty, 2013.

[20] A. Fathoni, Organisasi dan manajemen sumber daya manusia. Jakarta: Rineka Cipta, 2016.

[21] I. G. K. Ulupui, "Pengaruh partisipasi anggaran, persepsi keadilan distributif, keadilan prosedural, dan goal commitment terhadap kinerja dinas," J. Bus. Econ., vol. 9, no. 2, pp. 98-112, 2005.

[22] K. Wentzel, "The influence of fairness perceptions and goal commitment on managers' performance in a budget setting," Behav. Res. Account., vol. 14, pp. 247-271, 2008.

[23] R. Kreitner and A. Kanicki, Perilaku organisasi: Organizational behavior, Fifth. Jakarta: Salemba Empat, 2005. 